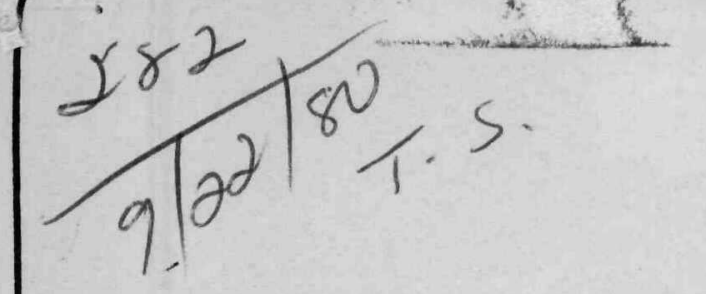

\title{
SERI /TP-731-756
}

UC CATEGORY: UC-62

$$
\text { CONF-800806- }-39
$$

THEMOELECTRIC PROPERTIES OF

BISMUTH-ANTIMONY THIN FILMS

JOHN TREFFNY

DEPARTMENT OF PHYSICS

COLORADO SCHOOL OF MINES

GOLDEN, COLORADO

T. S. JAYADEV

SOLAR ENERGY RESEARCH INSTITUTE

GOLDEN, COLORADO

JULY 1980

TO BE PRESENTEd at THE 15TH INTERSOCIETY ENERGY CONVERSION ENGINEERING CONFERENCE AUGUST 18-22, 1980

SEATTLE, WASHINGTON

PREPARED UNDER TASK NO. 3142.00

\section{Solar Energy Research Institute}

A Division of Midwest Research Institute

1617 Cole Boulevard

Golden, Colorado 80401

Prepared for the

U.S. Department of Energy

Contract No. EG-77-C-01-4042 


\section{DISCLAIMER}

This report was prepared as an account of work sponsored by an agency of the United States Government. Neither the United States Government nor any agency Thereof, nor any of their employees, makes any warranty, express or implied, or assumes any legal liability or responsibility for the accuracy, completeness, or usefulness of any information, apparatus, product, or process disclosed, or represents that its use would not infringe privately owned rights. Reference herein to any specific commercial product, process, or service by trade name, trademark, manufacturer, or otherwise does not necessarily constitute or imply its endorsement, recommendation, or favoring by the United States Government or any agency thereof. The views and opinions of authors expressed herein do not necessarily state or reflect those of the United States Government or any agency thereof. 


\section{DISCLAIMER}

Portions of this document may be illegible in electronic image products. Images are produced from the best available original document. 
Printed in the United States of America Available from:

National Technical Information Service

U.S. Department of Commerce

5285 Port Royal Road

Springfield, VA 22161

Price:

Microfiche $\$ 3.00$

Printed Copy $\$ 4.00$

\section{NOTICE}

This report was prepared as an account of work sponsored by the United States Government. Neither the United States nor the United States Department of Energy, nor any of their employees, nor any of their contractors, subcontractors, or their employees, makes any warranty, express or implied, or assumes any legal liability or responsibility for the accuracy, completeness or usefulness of any information, apparatus, product or process disclosed, or represents that its use would not infringe privately owned rights. 
John Treffny

Department of Physics

Colorado School of Mines

Golden, Colorado 80401

and

T. S. Jayadev*

Solar Energy Research Institute Golden, Colorado 80401

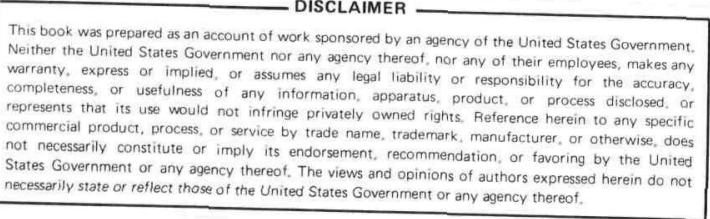

Introduction

Thermoelectrics have a wide range of potential applications in the temperature range of $0^{\circ}$ to $100^{\circ} \mathrm{C}$. In the area of power generation, there are a variety of low-grade heat sources (such as ocean thermal gradients, geothermal sources, and induscrial waste heat) that can be exploited to generate electric power using thermoelectrics. In the area of cooling, there is a growing market for industrial air conditioning, cooling of microcircuitry, and refrigeration down to cryogenic temperatures. Many of these applications can be realized if thermoelectric converters, given the situation of limited efficiency, can be made inexpensive. Present-day technology uses expensive materials and, more importantly, uses very expensive manufacturing techniques. Materials used in the temperature range of $0^{\circ}$ to $100^{\circ} \mathrm{C}$ are quaternary alloys of bismuth, antimony, selentum, and te1lurium. Processes used for device fabrication are elaborate with hundreds of $n$ and $p$ elements arranged individually and connected in series, resulting in excessive labor costs.

In an effort to enhance the feasibility of thermoelectrics, we have begun investigation of potentially cheaper materials and cheaper techniques for thermoelectrics. Two features of biswuth and ancimony have influenced our work. First, Horst and Williams ${ }^{2}$ have reported quite respectable figure of merit values in bulk single crystals of bismuth-antimony, up to $2.5 \times 10^{-3}$ at room temperature. Second, bismuth and antimony are an order of magnitude cheaper in cost compared to selenium and tellurlum, making this binary alloy a natural candidate to reduce the cost of thermoelectric devices. Our avenue of approach involves a simplification of the fabrication process using an established technique of solid-state electronics: thin-film deposition. We have recently begun to investigate the extent to which the favorable properties of bulk Bi-Sb are preserved in thin films. This paper reports some of the preliminary data coming out of this ongoing investigation.
Sample Preparation and Characterization

Our samples are prepared by simultaneous evaporation from heated crucibles contalning pure bismuth and pure antimony respectively. The simultaneous evaporation from separate crucibles causes a range of alloy compositions to deposit along the substrate. In our studies so far, we used 25-micron-thick mylar substrates held at room temperature for convenience. The films adhere well, generally have a smooth, uniform appearance, and can be handled easily. They have not shown any change in properties on exposure to atmosphere. Our film thicknesses to date have been on the order of 1 micron and have required evaporation times of about 20 minutes/micron at a starting pressure of $2 \times 10^{-5}$ torr. Copper contact strips, for use in the electrical neasurements, are deposited beforehand along the longitudinal edges of the substrate.

Following the deposition, we slice the film into transverse strips, each of approximately uniform composition, numbered consecutively from the antimony-rich to the bismuth-rich end. The oddnumbered strips are set aside for thickness measurements using a prectsion stylus gauge. Portions of these strips can be pulled from the substrate with adhesive tape. The heights of several of the steps thus formed, as measured by the stylus gauge, are averaged to deternine the thickness of each strip to $\pm 5 \%$.

The even-numbered strips are preserved for the electrical measurements. Their thicknesses are inferred by interpolation of the odd-numbered strip data. Finally, after the electrical properties have been determined, the compositions of the even-numbered strips are ascertained by $X$-ray fluorescence.

\section{Experimental}

Measurements of the Seebeck coefficient $\alpha$ and of the electrical resistance $R$ were carried out at remperatures ranging from $-100^{\circ} \mathrm{C}$ to over $+100^{\circ} \mathrm{C}$. For all of the measurements, the samples were clamped between two copper blocks that were indi- 
vidually equipped with heaters and therrocouples. The latter were in electrical as well as thermal contact with the copper blocks. The heaters were used to establish temperature differences across the samples, typically $2^{\circ}$ to $5^{\circ} \mathrm{C}$ as measured by the thernocouples. The Seebeck coeffielents of the samples relative to those of the thermocouple materials (copper, Constantan, and/or Chromel) were then determined by measuring the voltages induced across the approprlate thermocouple leads. All of the results were corrected to absolute values using standard tables. The coefficlents deduced from measurements relative to the several thermocouple materials generally agreed with one another to within $1 \mu \mathrm{V} /{ }^{\circ} \mathrm{C}$.

In a similar manner, the resistances of the filins were determined from two-lead resistance neasurements across the therrocouples, after subtracting the resistance of the thermocouple wires.

Three separace assemblies of the type fust described were used to cover the temperature range of interest. For measurements below room temperature, one assembly was situated in a vacuum chamber above a liquid nitrogen bath. For the high-temperature measurements, a second set-up was located in a sealed furnace. These measurements, at elevated temperatures, are usually carried out in an atmosphere of dry nitrogen or helium. inally, for work near room temperature, a third assembly was simply exposed to atr during the reasurements.

The use of three different apparatuses, each of which provided several quasi-independent seebeck coefficlents and resistance measurements, provided an ongoing cross-check of the results.

\section{Results and Conclusion}

The Seebeck coefficients of a series of three bismuch-rich films are displayed as a function of temperature in Fig. 1. In comparison, several results by previous authors on bulk, singlecrystal alloys are shown as well. The 1mportant aspect of the figure, and a principal result of this preliainary investigation, is that the Seebeck coefficients of evaporated alloy films are comparable to those which have been seen in wellprepared single crystals. This suggests that economical device development using these materfals may well be based on film technology rather than on bulk waterials processing.

The relatively large degree of scatter in our data may be due to difficulties in the clamping arrangements we used. Improved, positive thermal and electrical contact, through conductive paints, soft metal pads, or the like, should result in future data that are smooth on the scale of our instrumental resolution--1.e., $\pm 1 \mu \mathrm{V} /{ }^{\circ} \mathrm{C}$. However, our nain point (that the Seebeck coefficlents are comparable to those of bulk samples) is unaffected by this problem.

For increasing concentrations of antimony (increasing from Sample 1 to Sample 3), the Seebeck coefficient and electrical conductivity decreases. This behavior is similar to bulk material and could be explained by the model Horst and Williams have proposed. Prellminary annealing studies on these films show a marked increase in

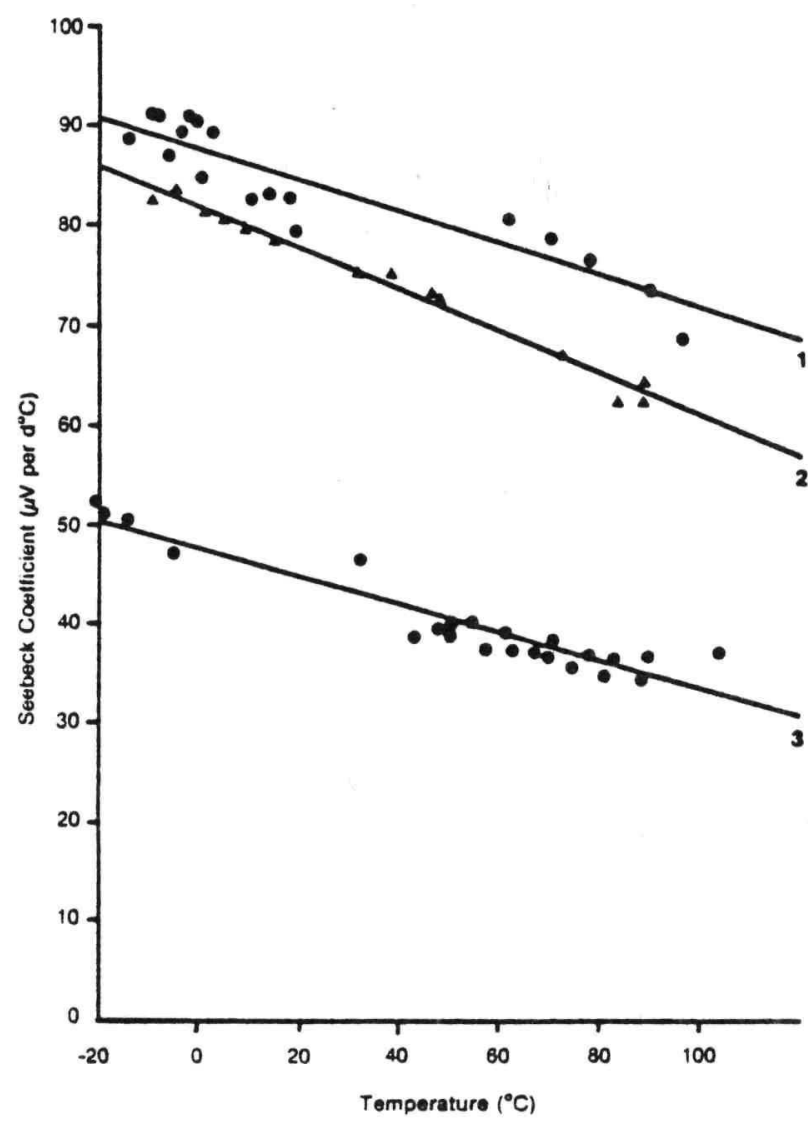

Figure 1. Plot of Seebeck Coefficient versus Temperature in Bismuth-Antimony Thin Films. (Antimony Concentration Increases from 1 to 3.)

Seebeck coefficient and electrical conductivity around $200^{\circ} \mathrm{C}$. The exact compositions of these films are being determined by $X$-ray fluorescence technique and w1ll be reported.

Our preliminary data indicate that thin films of bismuth-antimony, prepared by very simple means of thermal evaporation onto plastic substrates, are quite interesting from the point of view of inexpensive thermoelectric generator development. Values of Seebeck coefficients are similar to that of the bulk single crystals, but the electrical conductivities are somewhat lower. However, the physical processes (due to the structure of thin films) that decrease the electrical conductivity also decrease the electronle part of thermal conductivity. Therefore, the decrease in figure of merit of thin films ass compared to bulk may not be as serfous as the $\alpha^{2} \sigma$ product (F1g. 3) would indicate. Further investigations are progressing in the study of thermoelectric properties of these films using thicker samples (a few microns in thickness). We are also studying the effect of annealing, doping, and substrate temperature on thermoelectric properties, which are known to produce significant improvement in these properties in the bulk and in bismuth telluride thin films. ${ }^{3}$ The results of these investigations will be published later. 


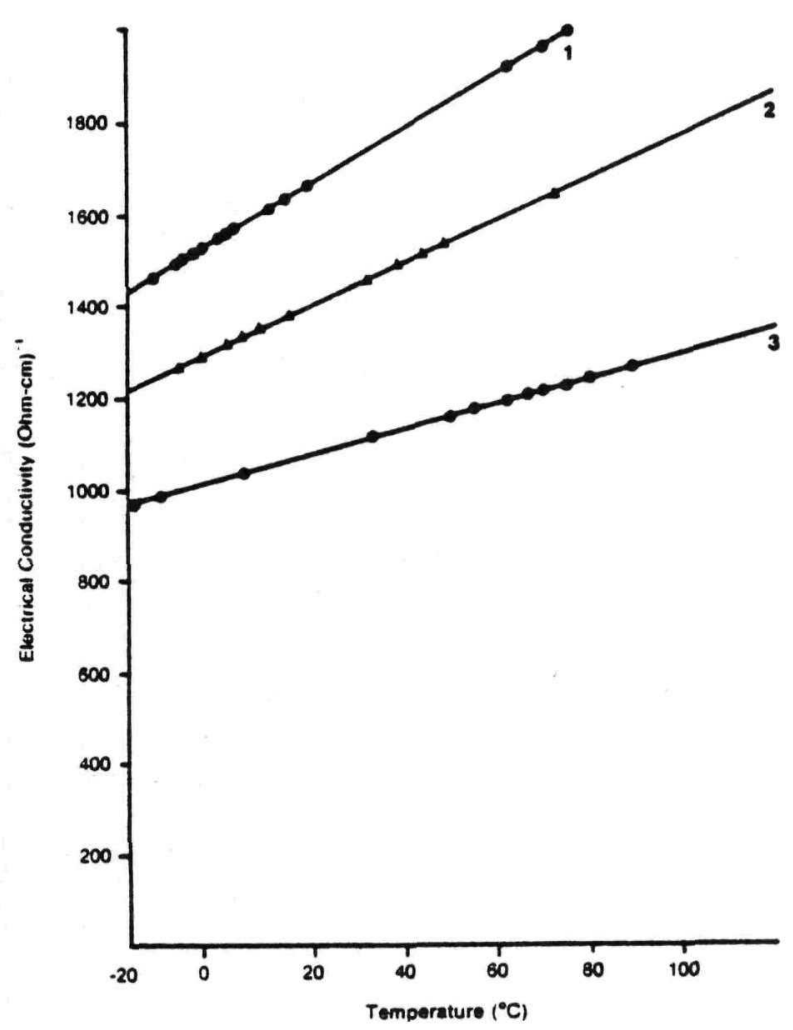

Figure 2. Plot of Electrical Conductivity versus Temperature in Bismuth-Antimony Thin Films. (Antimony Concentration Increases from 1 to 3. )

\section{References}

1. Jayadev, T. S. and Benson, D. K. "Thermoelectric Energy Conversion--Economic Electric Power from Low-Grade Heat." Proceedings of 3rd International Conference on Thermoelectric Energy Conversion. Arlington, TX; March 14, 1980 .

2. Horst, R. B. and Williams, L. R. "Potential Figure of Merit of the B1-Sb Alloys." Proceedings of 3rd Incernational Conference on Thermoelectric Energy Conversion. Arlington, TX; March 14, 1980 .

3. Harpster, J. "Vacuum Deposited TED's for Electric Device Chip Cooling." Proceedings of 2nd International Conference on Thermoelectric Energy Conversion. Arilngton, IX; March 22, 1978.

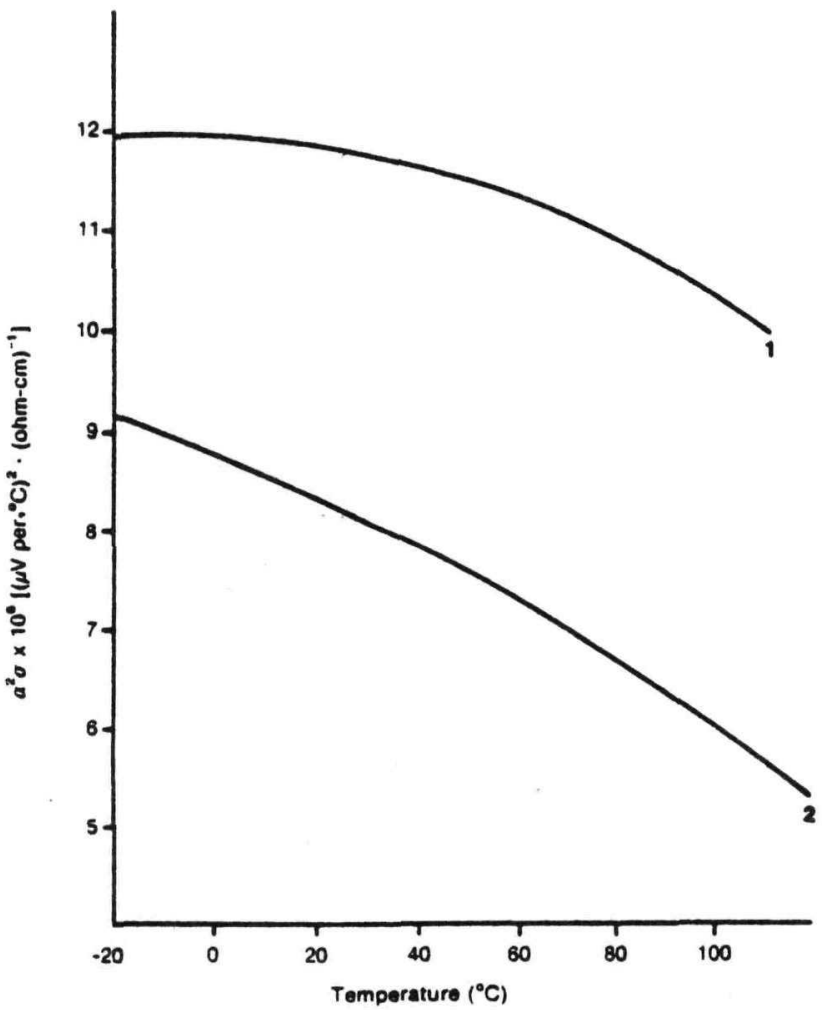

Figure 3. Plot of $a^{2} \sigma$ Factor versus Temperature in Bismuth-Antimony Thin Films. (Antimony Concentration Increases from 1 to 2.) 